\title{
Studies on the Multiplication of Apple Clonal Rootstock, Merton 793 through Cuttings
}

\author{
Ajender Negi, D. D. Sharma, Manish Thakur and Babita*
}

Dept. of Fruit Science, Dr. Y. S. Parmar University of Horticulture and Forestry, Nauni-Solan, H.P. (173 230), india

\section{Article History}

Manuscript No. AR1262

Received in $31^{\text {st }}$ January, 2015

Received in revised form $18^{\text {th }}$ July, 2015

Accepted in final form $25^{\text {th }}$ July, 2015

\section{Correspondence to}

*E-mail: babitasoniuhf@gmail.com

\section{Keywords}

Apple, clonal rootstock, IBA, wounding, rooting, vegetative growth

\begin{abstract}
The present investigation was conducted at Apple and Pear experimental block, Department of Fruit Science, Dr. Y.S. Parmar University of Horticulture and Forestry, Nauni, Solan (HP) under the net house during 2010-2011. The experiment was laid out in RBD design with three replications per treatment. There were in all ten treatments comprising of IBA application (three concentrations) and its combination with a basal wounding of cuttings (two procedures). IBA was used at 1000, 2000 and $3000 \mathrm{ppm}$ and wounding treatments included i) basal split and ii) vertical incision. In all there were nine combinations of IBA and wounding treatments and compared with control. The results obtained from the study revealed that highest percentage of rooted cuttings (46.66\%), number of main roots per cutting (15.67), length of main roots $(29.46 \mathrm{~cm})$, diameter of main roots $(3.84 \mathrm{~mm})$, total root length $(5.37 \mathrm{~m})$, fresh weight of roots $(9.17 \mathrm{~g})$, dry weight of roots $(4.90 \mathrm{~g})$, length of main shoot $(125.30 \mathrm{~cm})$, diameter of main shoot (171.8 mm), fresh weight of shoots (80.67 g), Dry weight of shoots (45.83 $\mathrm{g})$, shoot to root ratio (0.106), total number of leaves $(134.7)$, leaf area $\left(43.01 \mathrm{~cm}^{2}\right)$, total phenol content $\left(24.37 \mathrm{mg} \mathrm{g}^{-1}\right), \mathrm{C}: \mathrm{N}$ ratio (58.78) and total sugar content $(27.50$ $\mathrm{mg} \mathrm{g}^{-1}$ ) were recorded in the cuttings treated with IBA $2000 \mathrm{ppm}+$ Basal split.
\end{abstract}

\section{Introduction}

The Apple occupies a significant place in the horticultural wealth of Himachal Pradesh. It is the most subiquitous fruit crop among various temperate fruits grown in H.P. During the last two decades there was tremendous increase in the area under apple cultivation in the state. The area has increased from 3,025 hectares during 1960-61 to 2, 83, 000 hectares during 2009-10 (Anonymous, 2011). Hence, the demand of apple plantation stock has increased many folds in recent years. Besides this the increase in yield has not been in proportion to increase in area as most of the existing plantation has become old and senile. There has been continuous problem of replanting in such orchards where new plantation is unable to establish and plants remain stunted (under size) and die after few years. Among the various rootstocks used clonal rootstock, Merton 793 has been found promising under such conditions where replantation is a serious problem.Though, clonal rootstock, Merton 793 is employed mainly all over the world as replant solution but in India, seedlings still continues to be the most widely and commonly usedrootstock due to lack of awareness and limited supply of clonal rootstocks.Among the clonal rootstocks, Merton 793 has been proved to be an excellent rootstock because it is adapted to a wider range of soil, precocious as compared to seedling rootstocks, produces a vigorous tree, resistant to woolly apple aphid and collar rot and its excellent performance in replant situations.

Propagation through cuttings is the most common means of clonal regeneration of number of horticultural crops. Adventitious root formation is pre-requisite to successful cutting propagation (Hartmann et al., 2009). Clonal rootstocks are difficult-to-root and require some preconditioning treatments and use of growth regulators for better rooting. Various studies have revealed that preconditioning treatments like etiolation, girdling, periderm stripping coupled with growth regulators have to a great extent influenced the rooting ability of cuttings. So these treatments prior to growing cuttings have been found to enhance their rooting potential (Petridou and Voyiatzis, 1994; Porlingis et al., 1999). It was also reported that various growth regulators have been used since early days to increase rooting potentiality. Inducing rooting in the cuttings of apple rootstocks could be increased with the application of synthetic growth regulators. These growth regulators not only induce rooting but also improve the quality of rooted plantlets. Though, the application of auxins like IBA and NAA are 
essential for the rooting of cuttings of clonal rootstocks, but the some preconditioning treatments can enhance the absorption of the rooting agents and increases the rooting surface area of basal end and break the tissues impediments for root initiation. There is so far no report of use of these preconditioning treatments in rooting of cuttings in our condition. The response to wounding in the presence of IBA induced the stimulation of nodular callus from the region of the inner cortex and cambium which is exposed by wounding help in development of roots. (Howard et al., 1984). Keeping in view all these points, the study was carried out to ascertain the effect of preconditioning treatments in addition to plant growth regulators on rooting ability of apple clonal rootstock, Merton 793.

\section{Materials and Methods}

The present investigation was conducted at Apple and Pear experimental block, Department of Fruit Science, Dr. Y.S. Parmar University of Horticulture and Forestry, Nauni, Solan (HP) under the net house condition. Hardwood cuttings of apple clonal rootstock, Merton 793 of the size 25-30 cm long and thickness of $0.5-1.0 \mathrm{~cm}$ were collected in the month of December-January, 2010-11 when plants were dormant. While preparing the cuttings, care was taken to give a straight cut slightly below a node on the basal end and a slanting cut slightly above a node on the apical end. The propagation beds were prepared by mixing vermicompost, cocopeat, sand and forest soil in 1:1:1:1 ratio. Using a knife, cuttings were wounded at the base in one of the two ways. i) Four shallow diametrically opposite incisions at the base penetrating only into the outer cortex and extending upwards up to 25 mm. ii) A basal split through the diameter of the cutting and extending upwards for $25 \mathrm{~mm}$. The basal portion of the cutting was dipped for 5 seconds in IBA solution The treated cuttings were then placed in shade for few seconds to ensure sufficient absorption of IBA before planting in a nursery bed. The cuttings under control were treated with ethanol+distilled water. The cuttings were planted in the propagation beds in rows. The planting distance between row to row was kept as $15 \mathrm{~cm}$, whereas distance between adjacent cuttings was kept as $10 \mathrm{~cm}$, the entire experiment was laid out in RBD with three replications and twenty cuttings in each replication. The treatments were viz., T (IBA 1000 ppm), T (IBA 2000 ppm), $\mathrm{T}_{3}$ (IBA $3000 \mathrm{ppm}$ ), $\mathrm{T}_{4}$ (IBA1000 ppm+Basal Split), $\mathrm{T}_{5}$ (IBA 2000 ppm+Basal Split), $T_{6}$ (IBA 3000 ppm+Basal Split), $T_{7}$ (IBA1000 ppm+Basal Incision), $\mathrm{T}_{8}$ (IBA2000 ppm+Basal Incision), $\mathrm{T}_{9}$ (IBA3000 ppm+Basal Incision) and $\mathrm{T}_{10}$ (Control : Without IBA and Wounding). Number of treatments was ten and number of cuttings per treatment was twenty, method of IBA application was quick dip i.e. for fifteen seconds. The data obtained from the present investigations were subjected to statistical analysis as per procedure described by Gomez and Gomez (1984).

\section{Results and Discussion}

It is evident from the perusal of data presented in Table 1 that IBA alone or in combination with wounding exerted a significant effect on percentage of rooted cuttings. Highest per cent rooting of cuttings of clonal rootstock Merton 793 (46.66 \%) was recorded when IBA 2000 ppm along with basal split was applied $\left(\mathrm{T}_{5}\right)$, which was superior to all other treatments.

Table 1: Effect of IBA and wounding on per cent rooting and other root parameters of cuttings in clonal rootstock of apple, Merton 793

\begin{tabular}{|c|c|c|c|c|c|}
\hline Treatments & $\begin{array}{l}\text { Per cent } \\
\text { Rooting }\end{array}$ & $\begin{array}{l}\text { Avg. } \\
\text { no. of } \\
\text { main } \\
\text { roots }\end{array}$ & $\begin{array}{l}\text { Avg. } \\
\text { length } \\
\text { of main } \\
\text { roots } \\
(\mathrm{cm})\end{array}$ & $\begin{array}{l}\text { Avg. } \\
\text { diameter } \\
\text { of main } \\
\text { roots } \\
(\mathrm{cm})\end{array}$ & $\begin{array}{l}\text { Total } \\
\text { root } \\
\text { length } \\
(\mathrm{m})\end{array}$ \\
\hline $\begin{array}{l}\mathrm{T}_{1}: \text { IBA } 1000 \\
\text { ppm }\end{array}$ & $\begin{array}{c}22.23 \\
(28.13)\end{array}$ & 6.33 & 17.30 & 1.38 & 1.30 \\
\hline $\begin{array}{l}\mathrm{T}_{2}: \text { IBA } 2000 \\
\text { ppm }\end{array}$ & $\begin{array}{c}28.89 \\
(32.51)\end{array}$ & 7.33 & 14.62 & 1.60 & 1.67 \\
\hline $\begin{array}{l}\mathrm{T}_{3}: \text { IBA } 3000 \\
\text { ppm }\end{array}$ & $\begin{array}{c}24.44 \\
(29.62)\end{array}$ & 5.33 & 17.22 & 1.29 & 1.30 \\
\hline $\begin{array}{l}\mathrm{T}_{4}: \text { IBA } 1000 \\
\text { ppm+Basal } \\
\text { Split }\end{array}$ & $\begin{array}{c}33.33 \\
(35.26)\end{array}$ & 10.67 & 23.75 & 2.47 & 1.80 \\
\hline $\begin{array}{l}\mathrm{T}_{5}: \text { IBA2 } 2000 \\
\text { ppm+Basal } \\
\text { Split }\end{array}$ & $\begin{array}{c}46.66 \\
(43.09)\end{array}$ & 15.67 & 29.46 & 3.84 & 5.37 \\
\hline $\begin{array}{l}\mathrm{T}_{6}: \text { IBA } 3000 \\
\text { ppm+Basal } \\
\text { Split }\end{array}$ & $\begin{array}{c}35.55 \\
(36.60)\end{array}$ & 5.33 & 14.92 & 1.63 & 1.37 \\
\hline $\begin{array}{l}\mathrm{T}_{7}: \text { IBA1000 } \\
\text { ppm+Basal } \\
\text { Incision }\end{array}$ & $\begin{array}{c}31.11 \\
(33.90)\end{array}$ & 10.67 & 12.92 & 2.02 & 4.00 \\
\hline $\begin{array}{l}\mathrm{T}_{8}: \text { IBA2000 } \\
\text { ppm+Basal } \\
\text { Incision }\end{array}$ & $\begin{array}{c}40.00 \\
(39.23)\end{array}$ & 4.33 & 16.32 & 2.37 & 2.40 \\
\hline $\begin{array}{l}\mathrm{T}_{9}: \text { IBA3000 } \\
\text { ppm+Basal } \\
\text { Incision }\end{array}$ & $\begin{array}{c}35.55 \\
(36.60)\end{array}$ & 6.33 & 18.00 & 2.39 & 1.80 \\
\hline $\begin{array}{l}\mathrm{T}_{10} \text { : Control } \\
\text { (Without } \\
\text { IBA and } \\
\text { Wounding) }\end{array}$ & $\begin{array}{c}13.33 \\
(21.41)\end{array}$ & 3.00 & 13.58 & 0.95 & 1.10 \\
\hline $\mathrm{CD}(p=0.05)$ & 0.758 & 0.269 & 0.118 & 0.071 & 0.057 \\
\hline
\end{tabular}


Highest rooting characteristics viz., highest average number of main roots (15.67), average length of main roots $(29.46 \mathrm{~cm})$, average diameter of main roots $(3.84 \mathrm{~mm})$ and total root length $(5.37 \mathrm{~m})$ was also recorded with the treatment IBA $2000 \mathrm{ppm}$ + Basal Split $\left(\mathrm{T}_{5}\right)$. In case of average number of main roots treatment, IBA $2000 \mathrm{ppm}+$ Basal Split $\left(\mathrm{T}_{5}\right)$ recorded 15.67, which was significantly higher than all other treatments. In case of average diameter of main roots $(3.84 \mathrm{~cm})$ and for total root length $(5.37 \mathrm{~m})$, the treatment IBA $2000 \mathrm{ppm}+$ Basal Split $\left(\mathrm{T}_{5}\right)$ was significantly superior to other treatments. Fresh weight of roots $(9.17 \mathrm{~g})$ and dry weight of roots $(4.90 \mathrm{~g})$ was also significantly superior when IBA 2000 ppm was applied along with basal split (Figure 1). These results are in agreement with the findings of Nanda (1975) who also observed that IBA treatments increased the initiation of cell division and elongation in meristematic tissues, differentiation of cambial initials in to root primordia and helped in the mobilization of reserve food materials by enhancing the activity of hydrolyzing enzymes. Thus, it appears that IBA treatments had a marked effect on rooting as well as on rapidity of root and shoot development than control. Similar results were recorded by Pandey and Updhyay (1981), who obtained highest rooting, number and length of roots per cutting by treating peach hardwood cuttings with IBA 2000 ppm. Khabou et al. (1999) reported good rooting in olive cultivars Meski, Chemlali and Chemchali when their cuttings were treated with IBA between 1500-2000 ppm. Similarly, this concentration of IBA also favoured increase in root length in semi-hardwood cuttings of olive (Gautam and Chauhan, 1990). Wada et al. (1998) also reported that IBA promoted root length by influencing the synthesis of enzyme concerned in cell enlargement. The enzymes involved in cell enlargement process are triggered by auxin. Mohammad et al. (1989) observed that cuttings of

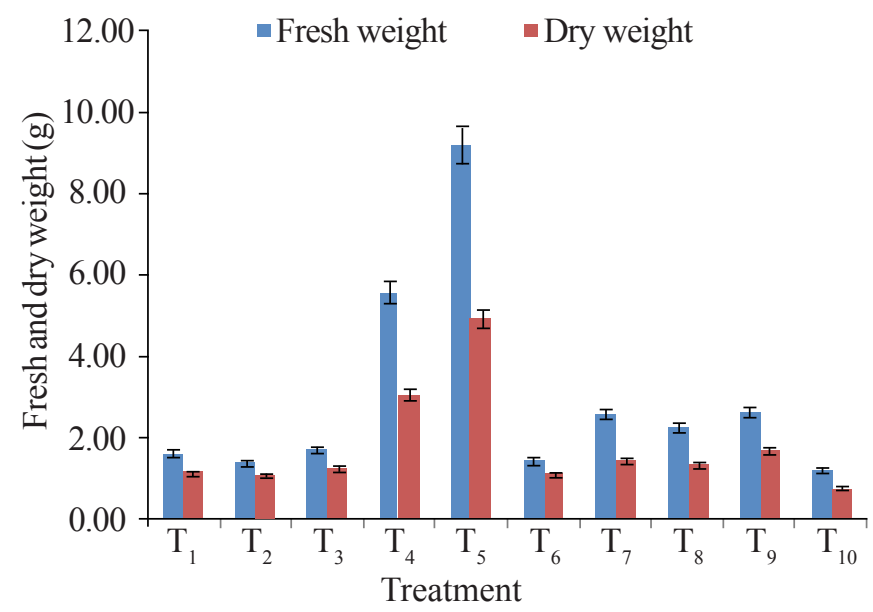

Figure1: Effect of IBA and wounding on fresh and dry weight of roots of cuttings in clonal rootstock of apple, Merton 793 peach rootstocks Peshawar Local and Nemaguard treated with IBA at 2000 ppm by quick dip methodgave higher number of roots per cuttings. Howard et al. (1984) reported wounding at the base of M 26 winter cuttings especially, by basal splitting to increase the number of roots in cuttings. Majumdar and Howard (1973) suggested that wounding increase the efficiency of auxin entry in to the stem and thus improve rooting of M9 apple clonal rootstock cuttings.

Highest shoot characteristics viz., average length of main shoot $(125.30 \mathrm{~cm})$, average diameter of main shoot $(171.8$ $\mathrm{mm})$, fresh weight of shoots $(80.67 \mathrm{~g})$ and dry weight of shoots $(45.83 \mathrm{~g})$ was recorded with application of IBA 2000 ppm along with basal split treatment (Table 2). For diameter of main shoot, fresh and dry weight of shoot the treatment IBA $2000 \mathrm{ppm}+$ Basal Split $\left(\mathrm{T}_{5}\right)$ was again significantly superior to all other treatments (Figure 2). On dry weight basis, highest root: shoot ratio (0.106) was again significantly superior for treatment IBA $2000 \mathrm{ppm}+$ Basal Split. These findings are in confirmation with Lal et al. (1971); Kale and Bhujbal (1972), who reported an improvement in quality of shoot characters due to one of the well known effect of IBA on elongation of root and shoot by way of cell division and cell elongation. Gautam and

Table 2: Effect of IBA and wounding on shoot characters in clonal rootstocks of apple, Merton 793

\begin{tabular}{lccc}
\hline Treatments & $\begin{array}{c}\text { Avg. length } \\
\text { of main } \\
\text { shoot }(\mathrm{cm})\end{array}$ & $\begin{array}{c}\text { Avg. di- } \\
\text { ameter of } \\
\text { main shoot } \\
(\mathrm{mm})\end{array}$ & $\begin{array}{c}\text { Root : } \\
\text { shoot ra- } \\
\text { tio (on dry } \\
\text { wt. basis) }\end{array}$ \\
\hline $\mathrm{T}_{1}$ : IBA 1000 ppm & 89.33 & 150.5 & 0.042 \\
$\mathrm{~T}_{2}$ : IBA 2000 ppm & 92.67 & 150.0 & 0.047 \\
$\mathrm{~T}_{3}$ : IBA 3000 ppm & 87.00 & 138.3 & 0.039 \\
$\mathrm{~T}_{4}$ : IBA1000 & 79.33 & 153.2 & 0.081 \\
ppm+Basal Split & & & \\
$\mathrm{T}_{5}:$ IBA 2000 & 125.30 & 171.8 & 0.106 \\
ppm+Basal Split & & & \\
$\mathrm{T}_{6}:$ IBA 3000 & 83.00 & 156.5 & 0.043 \\
ppm+Basal Split & & & \\
$\mathrm{T}_{7}:$ IBA1000 & 84.67 & 156.5 & 0.051 \\
ppm+Basal Incision & & & \\
$\mathrm{T}_{8}:$ IBA2000 & 102.70 & 165.2 & 0.041 \\
ppm+Basal Incision & & & \\
$\mathrm{T}_{9}$ : IBA3000 & 102.70 & 149.7 & 0.044 \\
ppm+Basal Incision & & & \\
$\mathrm{T}_{10}$ : Control & 71.33 & 138.2 & 0.032 \\
(Without IBA and & & & \\
$\begin{array}{l}\text { Wounding) } \\
\text { CD ( } p=0.05)\end{array}$ & 2.880 & 0.215 & 0.001 \\
\hline
\end{tabular}




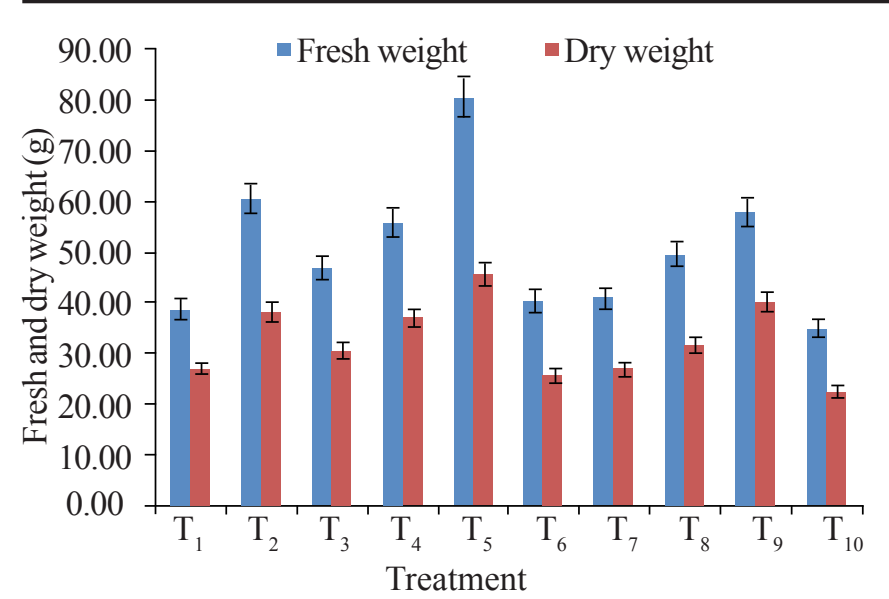

Figure 2: Effect of IBA and wounding on fresh and dry weight of shoots of cuttings in clonal rootstock of apple, Merton 793

Howard (1994) also recorded that preconditioning treatments along with IBA application resulted in better shoot growth in Hazelnut leafy cuttings. These findings are in conformity with those of Ishtiaq et al. (1989), who obtained maximum increase in stem diameter per cutting in peach rootstocks Peshawer Local and Nemaguard when treated with IBA $2000 \mathrm{ppm}$. Biasi et al. (1990) also recorded higher dry weight content of shoots with the increased concentration of IBA.

Highest number of leaves (134.7) and leaf area $\left(43.01 \mathrm{~cm}^{2}\right)$ were recorded for with the treatment IBA $2000 \mathrm{ppm}+$ Basal Split $\left(\mathrm{T}_{5}\right)$ and was found significantly superior to all other treatments (Table 3). A similar trend was observed with the application of auxin to semi-hardwood cuttings of guava, which has a significant effect on increasing the number of leaves. The increased roots in the cuttings due to auxin application may be due to increased photosynthesis and other activities carried out in the leaves, which in turn may have resulted in the increase of leaf area in the cuttings (Taiz and Zeiger, 2006).

Total phenol content $\left(24.37 \mathrm{mg} \mathrm{g}^{-1}\right), \mathrm{C}: \mathrm{N}$ ratio (58.78) and total sugars $\left(27.50 \mathrm{mg} \mathrm{g}^{-1}\right)$ was also recorded highest when IBA $2000 \mathrm{ppm}$ applied along with basal split treatment and was significantly superior to all other treatments (Table 3 ). The present findings are also supported by Nanda and Kochhar (1985), who had reported a positive correlation between phenolic compounds and rooting of cutting in some easy to root plants. Bhatia and Jindal (2000) also observed the highest total phenols in the shoots of semi-dwarfing MM106 rootstock followed by M4, MM109 and seedling rootstocks. The increase in the level of carbohydrate in the auxin treated cuttings, support the contention that auxin induce hydrolysis of complex substances. Stock plants under high carbohydratenitrogen ratio are optimal for rooting in cuttings under mist (Rein et al., 1991). These observations are in agreement with those of Kraus and Kraybill (1998); Hartmann and Kester
Table 3: Effect of IBA and wounding on leaf characters in clonal rootstock of apple, Merton 793

\begin{tabular}{lccccc}
\hline Treatments & $\begin{array}{c}\text { Total } \\
\text { no. of } \\
\text { leaves }\end{array}$ & $\begin{array}{c}\text { Leaf } \\
\text { area } \\
\left(\mathrm{cm}^{2}\right)\end{array}$ & $\begin{array}{c}\text { Total } \\
\text { phenol } \\
\text { content } \\
\left(\mathrm{mg} \mathrm{g}^{-1}\right)\end{array}$ & $\begin{array}{c}\text { C:N } \\
\text { ratio }\end{array}$ & $\begin{array}{c}\text { Total } \\
\text { sugar } \\
\left(\mathrm{mg} \mathrm{g}^{-1}\right)\end{array}$ \\
\hline $\mathrm{T}_{1}$ : IBA 1000 ppm & 81.67 & 24.55 & 19.20 & 27.69 & 22.16 \\
$\mathrm{~T}_{2}$ : IBA 2000 ppm & 97.67 & 30.91 & 20.40 & 42.28 & 23.52 \\
$\mathrm{~T}_{3}$ : IBA 3000 ppm & 80.33 & 28.88 & 18.53 & 26.25 & 19.57 \\
$\mathrm{~T}_{4}$ : IBA1000 & 101.00 & 21.78 & 22.50 & 39.51 & 22.77 \\
ppm+Basal Split & & & & & \\
$\mathrm{T}_{5}:$ IBA 2000 & 134.70 & 43.01 & 24.37 & 58.78 & 27.50 \\
ppm+Basal Split & & & & & \\
$\mathrm{T}_{6}:$ IBA 3000 & 79.67 & 21.75 & 19.80 & 40.17 & 22.23 \\
ppm+Basal Split & & & & & \\
$\mathrm{T}_{7}:$ IBA1000 & 89.00 & 21.68 & 19.03 & 38.80 & 23.42 \\
ppm+Basal & & & & & \\
Incision & & & & & \\
$\mathrm{T}_{8}$ : IBA2000 & 95.00 & 39.94 & 20.87 & 42.00 & 26.57 \\
ppm+Basal & & & & & \\
$\begin{array}{l}\text { Incision } \\
\mathrm{T}_{9} \text { : IBA3000 } \\
\text { ppm+Basal }\end{array}$ & 78.67 & 34.85 & 20.13 & 41.60 & 21.11 \\
Incision & & & & & \\
$\mathrm{T}_{10}$ : Control & 54.67 & 20.89 & 17.73 & 23.27 & 17.73 \\
$\begin{array}{l}\text { Without IBA and } \\
\text { Wounding) }\end{array}$ & & & & & \\
CD ( $p=0.05)$ & 1.117 & 0.085 & 0.082 & 0.065 & 0.088 \\
\hline
\end{tabular}

(1983) who reported that the cuttings high in carbohydrate and low in nitrogen contents, generally, produce good rooting. Singh (1985) reported that auxin treated cuttings had more total sugars as compared to untreated cuttings.

\section{Conclusion}

Among the different concentrations of IBA and wounding alone or in combination, the treatment IBA $2000 \mathrm{ppm}+$ Basal Split $\left(\mathrm{T}_{5}\right)$ was found to be the best treatment for inducing better root system in terms of rooting percentage, number of roots, root to shoot ratio, total root length, fresh and dry weight of roots and biochemical aspects including total phenol content, carbohydrate-nitrogen ratio, total sugar content in the shoots and other parameters of commercial importance in clonal rootstock of apple Merton793.

\section{References}

Anonymous, 2011. Status of Horticultural crops in Himachal Pradesh. Department of Horticulture, Himachal Pradesh, 
Shimla 2, HP. India

Bhatia, S.K., Jindal, K.K., 2000. Effect of growth retardant, rootstock and scion combination on the contents of carbohydrates and phenol in leaf and shoot of apple. Haryana Journal of Horticulture Science 29(3/4), 171173.

Biasi, R., Marino, G., Costa, G., 1990. Propagation of Hayward kiwifruit (Actinidia deliciosa) from soft and semihardwood cuttings. Acta Horticulturae 282, 243-250.

Gautam, D.R., Chauhan, J.S., 1990. Standardization of IBA concentration and season on rooting of wild olive cutting under intermittent mist. Indian Journal of Horticulture 47(3), 278-285.

Gautam, D.R., Howard, B.H., 1994. Influence of some preconditioning treatments and propagation environments on the rooting of hazelnut leafy stem cuttings. Acta Horticulturae, 351, 361-369.

Gomez, K.A., Gomez, A.A., 1984. In:Statistical Procedure for Agricultural Research $2^{\text {nd }}$ ed. New York: Willey Interscience, 304-309.

Hartmann, H.T., Kester, D.E., 1983. Plant propagation principles and practices $4^{\text {th }}$ ed. Prentice Hall of Indian Pvt. Ltd., 242-243.

Hartmann, H.T., Kester, D.E., Fred, T.D., Robert, L., Geneve, R.L., 2009. In: Plant Propagation Principles and Practices, 7 edition, Prentice Hall, New Delhi, 1039.

Howard, B.H., Harrison Murray, R.S., Mackenzie, A.D., 1984. Rooting responses to wounding winter cuttings of M-26 apple rootstock. Journal of Horticulture Science 59(2), 131-139.

Ishtiaq, M., Haq, I., Ayaz, M., 1989. Initiation of roots in Peach rootstock cvs. Peshawar local and Nemaguard as affected by Indolebutyric acid. Sarhad Journal of Agriculture 5, 41-45.

Kale, P.N., Bhujbal, B.G., 1972. Use of growth regulators in rooting of cuttings of bougainvillea var. Mary Palmer. Indian Journal of Horticulture 29(3/4), 307-309.

Khabou, W., Drira, N., 1999. Variation in the rooting of leafy stem cuttings of olive varieties and clones (Olea europaea L.) cultivated in Tunisia. Olivae 84:47-49. [cf. Horticultural Abstracts, 2001, 71(11), 9396]
Krous, S.K., Kreybill, E.J., 1998. Vegetation and reproduction with special reference to tomato. Oregan Agricultural Experiment Station Bulletin 49, 1-90.

Lal, N., Yadav, S.N., Srivastava, L.S., 1971. Effect of some plant growth regulators on rooting behavior of bougainvillea cv. Thimma. Punjab Horticulture Journal 11(1-2), 278-279.

Majumder, P.K., Howard, B.H., 1973. The response to M-9 hard wood cuttings to various root inducing treatment. Report of East Malling Research Station for 1978, 74.

Mohammad, I.I.H., Ayaz, M., 1989. Initiation of roots in peach in peach rootstock cv. Peshawar Local and Nemaguard as affected by indole butyric acid. Sarhad Journal of Agriculture 5(1), 41-45.

Nanda, K.K., 1975. Physiology of adventitious root formation. Indian journal of Plant Physiology 18, 80-90.

Nanda, K.K., Kochhar, V.K., 1985. Vegetative propagation of plants $1^{\text {st }}$ Edn. Kalyani Publishers, New Delhi, 130133.

Pandey, D., Upadhyay, S.N., 1981. A note on the propagation of peach by hardwood cuttings. Progressive Horticulture 13, 171-177.

Petridou, M., Voyiatzis, D.G., 1994. Beneficial effect of girdling, auxin, tween-20 and paclobutrazole on the propagation of olive by an improved method of mound layering. Acta Horticulturae 356, 24-29.

Porlingis, I.C., Petridou, M., Voyiatzis, D.G., 1999. Improved method of propagating the olive by mound- layering. Acta Horticulturae 474, 59-62.

Rein, W.H., Wright, R.D., Seiler, J.R., 1991. Stock plant nutrition influences the adventitious rooting of 'Rotundifolia' holly stem cuttings. Journal of Environmental Horticulture 9, 83-85.

Singh, S.P., 1985. Study of carbohydrate and nitrogen fractions in semi hardwood cuttings of Pyrostagia venusta at root emergence. Haryana Journal of Horticulture Science 14(3-4), 199-203.

Taiz, L., Zeiger, E., 2006. Plant Physiology. $4^{\text {th }}$ Edn. Sinauer Associates Inc Publisher, 84-86. 